Studies in African Linguistics

Volume 39, Number 1, 2010

\title{
THE VERBAL MORPHOLOGY AND PHONOLOGY OF ASANTE TWI ${ }^{*}$
}

\author{
Mary Paster \\ Pomona College
}

\section{Introduction}

This paper presents an analysis of the verbal morphology and associated phonological processes in Asante Twi, a member of the Akan group of languages/dialects spoken in Ghana and Côte d'Ivoire, which belongs to the Nyo subgroup of the Kwa language family (Lewis 2009). There has been considerable interest in Akan in the theoretical literature, largely due to some peculiarities in the tense/aspect system which will be addressed later in this paper. However, the verbal morphology and phonology have been given relatively little attention. In this paper I show that the verbal morphology exhibits a number of interesting properties including tonal marking of tense/aspect categories - the latter having been largely ignored or misrepresented in the previous literature.

\section{Background on Akan and Asante Twi}

The most well-known of the Akan dialects are Asante Twi, Akuapem Twi, and Fante. The name 'Twi' is often used to refer to the Asante and Akuapem dialects to the exclusion of Fante; hence it is not always clear which dialect is intended when a particular claim is made about 'Akan' or 'Twi'. There is a tendency in the literature to describe all three of the major Akan dialects together, which has a confounding effect whenever tone is relevant, since some of the most significant differences among these dialects are tonal. Relatedly, many sources present examples in the standard Akan orthography, which does

\footnotetext{
* I would like to thank my consultants for providing the data for this project, and Cynthia Castillo and Amelia Compton for assistance with sound files. I am also grateful to Michael Marlo, Laura McPherson, Dave Odden, and the SAL reviewers for very helpful comments on earlier drafts of this paper, and to Jay Atlas, Stuart Davis, Stephanie Harves, members of the PhonLunch group at USC, audience members at ACAL 40, and students in the Topics in Phonology seminar at Pomona College for valuable input.
} 
not mark tone, so tone is often omitted. In this paper, I focus on only one dialect (Asante) and I will depart from the conventional use of the Akan orthography in order to mark tone in my examples. All examples are from Asante Twi and are from my own notes, except where specified. ${ }^{1}$

The most thorough existing descriptions of the verbal morphology are found in Dolphyne 1965, 2006. The latter provides partial verb paradigms and a description of the phonology and morphology of three Akan dialects, but it does not give a full morphological analysis of the verbal tense/aspect system. There are some discrepancies between what Dolphyne 2006 reports and what my own consultants produce in some areas of the morphology and phonology, some of which I point out below. It is not entirely clear what accounts for these differences, but some possibilities include interspeaker variation (perhaps based on a generational difference) and the fact that Dolphyne simultaneously describes three Akan dialects while my focus is solely on Asante Twi. Other resources include Boadi 2008, which gives a partial analysis of the verbal morphology, and the discussion of Akan morphology and/or phonology found in Schachter and Fromkin 1968, Essilfie 1986, Osam 1994, Saah 1994, Dolphyne 1996, Ofori 2006a,b, and Stump 2009.

Asante Twi, like other Akan dialects, has two tones, High $(\mathrm{H})$ and Low (L) (in this paper, $\mathrm{H}$ is marked by an acute accent (á), and $\mathrm{L}$ is marked by a grave accent (à); downstep is marked by a superscripted exclamation mark ('á)).

The following verb root shapes are attested in Asante Twi (where $\mathrm{C}=$ consonant, $\mathrm{V}=$ vowel, $\mathrm{R}=$ sonorant consonant, $\mathrm{G}=$ glide, and $\mathrm{O}=$ obstruent): CV H, CVR(V) HL, CVR(V) LH, CVV LH (of which those whose first vowel is round surface as $[\mathrm{CGV}]$ due to a Glide Formation rule, with accompanying tone changes, while the others surface as [CVV]; this will be discussed further below), and CVOV LH. Dolphyne (1996) identified a number of 'root types' (for Akan, rather than Asante Twi specifically), which divided the root shapes into separate categories based on their behavior in different tense/aspect categories: CV H, CV L, Tone Group 1 (which consists of CVR(V) LL and CVR(V) HL verbs), Tone Group 2 (which consists of CVR(V) LH, CCV LH, and CVV LH verbs), and Tone Group 3 (which consists of CVOV LH verbs). I depart from Dolphyne (1996) in that I have no evidence for CV L verbs in my data, nor for CVR(V) LL verbs, and I do not make use of the concept of 'tone groups'. Rather, I will demonstrate how grammatical tones and lexical tones interact straightforwardly via regular phonological rules of the language to produce the surface tone patterns regardless of root shape. Therefore, although

\footnotetext{
${ }^{1}$ This study is based on data from two young people (18-34; KD - male, EA - female), both native speakers of Asante Twi, and both having exposure to the Akuapem dialect. Data in this paper are from KD except where noted.
} 
in each tense/aspect category described below I will provide examples of verbs with each of the shapes mentioned earlier, these should not be taken as significant categories in the grammar.

\section{Asante Twi verbal morphology}

In this section I provide data showing how each verb type is manifested in each tense/aspect category (note that I am treating [CGV] LH and [CVV] LH as different types for this purpose, even though they are both underlyingly /CVV/). In order to show the tone of the verb clearly, each verb is followed by an object since there is a Final Lowering rule that changes $H$ tones to $L$ in utterance-final position (this rule complicates the analysis of the verbal tone unless an object is present to 'protect' the verb from its effect). The tense/aspect categories are presented in groups based on the type of morpheme used to mark them: prefixes vs. suffixes and/or $\mathrm{H}$ vs. L tones. Where relevant, I will introduce regular phonological processes that account for the surface forms of the different verb types in a given category. For each verb, I give four examples - one with a $\mathrm{H}-$ toned subject (the name 'Esi'), one with a L-toned subject (the name 'Yaw'), one with a H-toned pronominal subject (2sg wó, 2pl mó, or 3pl j́mó), and one with a L-toned pronominal subject (1sg mì, $1 \mathrm{pl} y \dot{\varepsilon}, 3 \mathrm{sg}$ human $\dot{\partial}$, or $3 \mathrm{sg}$ nonhuman $\grave{\varepsilon}$ ) (the difference is significant since, as will be seen in the examples, in some tense/aspect categories, verbs have different tone patterns depending on the underlying tone of the subject, and in some cases the tone of the subject is altered depending on the tense/aspect).

3.1 Categories with no tone marking on the verb root. The Habitual is not marked by any tone, or by any segmental prefix or suffix. Thus, the Habitual reflects the underlying form of verb roots more straightforwardly than any other tense/aspect category. Examples are given in (1) (note: underlining indicates nasality). 
(1) a. $\mathrm{CV} \mathrm{H}$
ésí tó pèn
'Esi buys pens'
mó tó pèn
'You pl. buy pens.'
yàw tó pèn
'Yaw buys pens.'
yè tó pèn
'We buy pens.'

b. CVR(V) HL

ésí nôm ìnsyù

wó nôm ìnsyù

yàw nôm ìnsyù

mì nôm ìnsyù

c. $\mathrm{CVR}(\mathrm{V}) \mathrm{LH}$

ésí dàné nè hô

mó dàné mò hô

yàw dàné nè hâ

mì dàné mì hô
'Esi drinks water'

'You drink water.'

'Yaw drinks water.'

'I drink water.'

d. CGV LH (/CVV/)

ésí 'bwá yàà

wó 'bwá yàà

yàw bwá yàà

mì bwá yàà
'Esi turns herself.'

'You pl. turn yourselves.'

'Yaw turns himself.'

'I turn myself.'

e. CVV LH

ésí kàé kòfi

mó kàé kòfî

yàw kàé kòfî

j̀ kàé kòfî
'Esi helps Yaa.'

'You help Yaa.'

'Yaw helps Yaa.'

'I help Yaa.'
'Esi remembers Kofi.'

'You pl. remember Kofi.'

'Yaw remembers Kofi.'

'He remembers Kofi.' 


\section{f. CVOV LH}
ésí bìsá àsèm
'Esi asks something.'
wó bìsá àsèm
'You ask something.'
yàw bìsá àsèm
'Yaw asks something.'
ò bìsá àsèm
'He asks something.'

The forms in (1)d exhibit Glide Formation, which deletes the mora belonging to a labial (round) vowel, changing it to [w] when it precedes another vowel within the word. The rule is schematized below.

Glide Formation

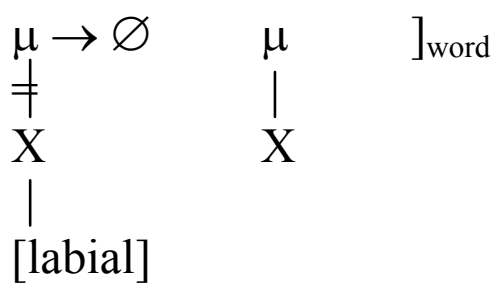

There are several arguments for assuming that this verb's underlying form is /boa/ and that Glide Formation applies to it. First, as we will see later, Glide Formation applies productively across the language, in some cases resulting in alternations, so the rule is independently motivated (and as will be discussed later, this verb does surface as [boa] in the past tense). Second, assuming /boa/ as the underlying form of the root helps us to understand its otherwise anomalous tone pattern. There are no verbs with a consistent $\left[{ }^{\prime} \mathrm{H}\right]$ tone pattern, suggesting that there is no group of $/ ! \mathrm{H} /$ verbs. There are, however, $\mathrm{LH}$ verbs. The tone pattern on this verb makes sense if we assume that it is underlyingly LH. Elsewhere in the language, contour tones generally occur only where there are two moras; as also observed by Dolphyne (2006: 66), there are no rising tones observed on syllables with only a short vowel in the rime. The verb 'help' can be made consistent with this generalization if we assume that it is underlyingly bimoraic, i.e., /boa/ rather than /bwa/. In this analysis, the L tone is underlyingly linked to the first mora, which is lost when the /o/ undergoes Glide Formation. This leaves the L tone 'floating', and this $\mathrm{L}$ is then manifested as a downstep on the following $\mathrm{H}$ tone. A sample derivation for this verb is given in (3) (a circle around a tone indicates a floating tone). 
Derivation of wó 'bwá yàà

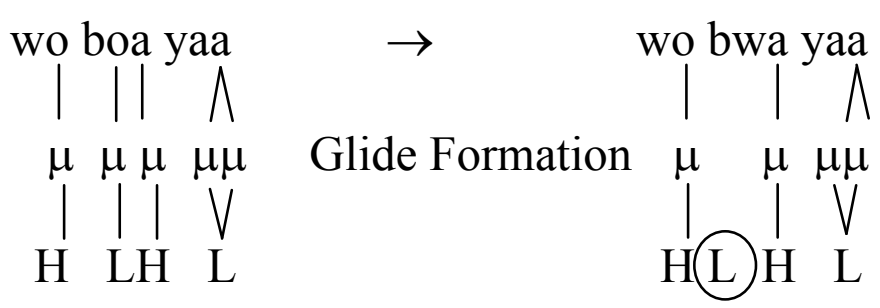

The ' $\mathrm{H}$ tone pattern occurs on this verb anytime it is preceded by a $\mathrm{H}$ tone (either a H-toned subject or a H-toned prefix, such as the Future prefix to be discussed later). No downstep is evident in the forms yàw bwá yàà or mì bwá yàa because the subjects are L-toned, but I assume that there is a floating L tone at some point in the derivation of these forms as well; this $\mathrm{L}$ is either merged with the preceding (linked) L tone or else it remains until the end of the derivation but has no phonetic effect since it does not occur between two $\mathrm{H}$ tones.

A second rule that applies in the data above is ATR Harmony (4), which changes a [-ATR] vowel in a prefix to [+ATR] when the first vowel of the stem ${ }^{2}$ is [+high, +ATR]. Notice that in (1)f, the $3 \mathrm{sg}$ pronoun surfaces as [o] rather than [0]. This is due to the [+ATR] vowel in the first syllable of the verb stem bisa.

ATR Harmony

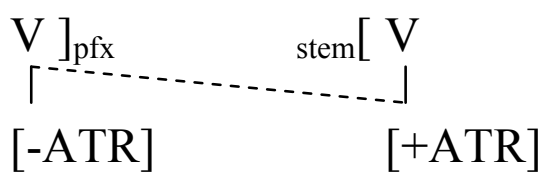

One point about ATR Harmony that is relevant to the data being discussed in this paper is that the [+ATR] counterpart of /a/ is /e/. Dolphyne treats the [+ATR] low vowel as being distinct from /e/ (in Twi but not in Fante), but they are indistinguishable in my consultants' speech. A table showing the [-ATR] vowels and their $[+\mathrm{ATR}]$ counterparts is shown in (5).

\footnotetext{
${ }^{2}$ Note that 'stem' refers to the 'stem of attachment' for the target prefix. I am assuming that words are built from the inside out, such that the stem of attachment for a particular prefix includes the root plus any affixes already attached to the root. This is what accounts for the fact, to be discussed below, that ATR harmony applies iteratively from the root into a prefix, and then into another prefix to its left.
} 


$\begin{array}{cc}\text { [-ATR] } & \text { [+ATR] } \\ \mathrm{a} & \mathrm{e} \\ \varepsilon & \mathrm{e} \\ \mathrm{I} & \mathrm{i} \\ \mathrm{o} & \mathrm{o} \\ \mathrm{v} & \mathrm{u}\end{array}$

ATR Harmony is an iterative rule, applying to the vowels in any number of prefixes (whether subject prefixes or tense/aspect markers). For example, in the immediate future form mó ò-bè-bisá àsèm 'you pl. are about to ask something', the [+ATR] value of the /i/ in bisa spreads leftwards through the prefix /bغ̀-/ (changing it to [bè]) and the progressive prefix (which is realized here as $\dot{o}-$ ), all the way to the $2 \mathrm{pl}$ pronoun /mó/ (changing it to [mó]). Note, however, that the rule will not apply to a prefix vowel that is followed by a [+ATR] vowel within the same prefix. In particular, the $3 \mathrm{pl}$ subject pronoun invariably surfaces as '́mó; its initial, [-ATR] vowel never harmonizes with the final, [+ATR] vowel. This follows from the requirement that the triggering vowel be part of the stem. See Dolphyne (2006) for further discussion of ATR harmony; note, however, that rather than the IPA symbols being used here, Dolphyne uses the vowel symbols from the Akan orthography, modified with diacritics (the orthography has only seven vowels, using $<\mathrm{e}>$ for IPA [e] and [I], and $<_{0}>$ for [o] and $\left.[\mho]\right)$.

The negative habitual is also not marked with a tone on the root; it consists of a regular habitual form plus the negative prefix /ǹ-/. Examples are given below. ${ }^{3}$

\section{a. $\mathrm{CV} \mathrm{H}$}

$\begin{array}{ll}\text { ésí ń-'tó pèn } & \text { 'Esi doesn't buy pens.' } \\ \text { wó ń-'tó pèn } & \text { 'You don't buy pens.' } \\ \begin{array}{l}\text { yàw ǹ-tó pèn } \\ \text { mì ǹ-tó pèn }\end{array} & \text { 'Yaw doesn't buy pens.' } \\ \end{array}$

${ }^{3}$ Stump (2009: 200) claims that Negative forms of some categories (including the Habitual) have the tone reversed on the root-initial syllable. However, a comparison between the Habitual and Negative Habitual examples in this paper shows that the tone of the root remains the same, modulo the effects of the Tonal Plateauing rule described below. 
b. CVR(V) HL

ésí ń-'nôm ìnsyù

wó ń-'nôm ìnsyù

yàw ǹ-nôm ìnsyù

mì ǹ-nôm ìnsyù
'Esi doesn't drink water.'

'You don't drink water.'

'Yaw doesn't drink water.'

'I don't drink water.'

c. $\mathrm{CVR}(\mathrm{V}) \mathrm{LH}$

ésí ń-dàné nè hô

mó ń-dàné mò hô

yàw ǹ-dàné nè hô

mì ǹ-dàné mì hô
'Esi doesn't turn herself.'

'You don't turn yourselves.'

'Yaw doesn't turn himself.'

'I don't turn myself.'

d. CGV LH (/CVV/)

ésí ḿ-'mwá yàà

wó ḿ-'mwá yàà

yàw m̀-mwá yàà

mì m̀-mwá yàà
'Esi doesn't help Yaa.'

'You don't help Yaa.'

'Yaw doesn't help Yaa.'

'I don't help Yaa.'

e. CVV LH

ésí ń-'káé kòfi

wó ń-'káé kòfî

yàw ì-kàé kòfî

mì ỳ-kàé kòfî
'Esi doesn't remember Kofi.'

'You don't remember Kofi.'

'Yaw doesn't remember Kofi.'

'I don't remember Kofi.'

\section{f. CVOV LH}

ésí ḿ-'mísá àsèm wó ḿ-'mísá àsèm

yàw m̀-mìsá àsèm mì m̀-mìsá àsèm
'Esi doesn't ask something.'

'You don't ask something.'

'Yaw doesn't ask something.' 'I don't ask something.' 
Notice that tone is transcribed on the nasal prefixes in (6), but in fact their surface tone is predictable: it is identical to the tone of the preceding mora (the negative prefix still needs to have an underlying $\mathrm{L}$ tone, however, in order to explain the presence of a downstep before $\mathrm{H}$-initial verbs, as in (6)a and b). This seems to be true throughout the data regardless of whether the nasal syllabifies with the preceding mora (as can be assumed in examples such as wó n'-'t'́ pèn 'you don't buy pens') or not (as might be argued for examples such as yàw ì-t'́ pèn 'Yaw doesn't buy pens'). This can be accounted for via a rule of Nasal Tone Assimilation, given in (7) ( $\mathrm{T}$ stands for any tone, $\mathrm{H}$ or $\mathrm{L}$ ).

Nasal Tone Assimilation

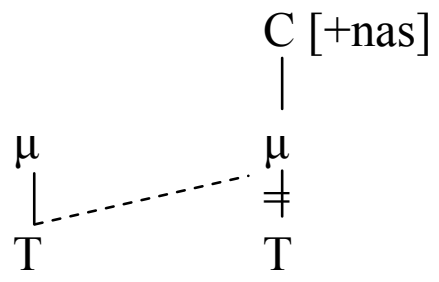

The rule must apply relatively early in the derivation since it feeds another rule, Tonal Plateauing, to be discussed later in the paper.

Another set of phonological processes is at work in the data in (6). First, in (6) $\mathrm{d}, \mathrm{f}$, the verbs /boa/ and /bisa/ surface with initial [m]. This is due to a rule of Labial Nasalization, where $/ \mathrm{b} /$ becomes $[\mathrm{m}]$ after a nasal consonant. This rule is given in (8).

Labial Nasalization

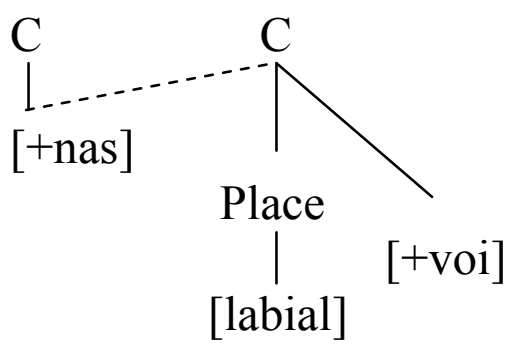

Labial Nasalization is an optional rule; in this paper I have given transcriptions that reflect Labial Nasalization where applicable, but all of these examples have fully grammatical counterparts in which Labial Nasalization does not apply. Note also that Labial Nasalization applies only within words, not across word boundaries. This can be seen in examples such as èntớntớm bé bisá àsèm 'Mosquito will ask something' and èntớntớm bisá àsèm 'Mosquito asks something', where *èntơntớm mé bìsá àsc̀m and *èntơntớm bìsá àsèm, 
respectively, are ungrammatical. A final note about Labial Nasalization is that it differs somewhat from the rule described by Dolphyne (2006: 141-142). In the variety of Asante Twi described by Dolphyne, all plosives and affricates (not just labials) become nasals when preceded by a nasal consonant, yielding forms such as $n n a$ from /nda/ and $\eta \eta o$ from /ngo/ (2006: 1952; tones and glosses not given). Although my consultants do not outright reject forms like these in which nasalization applies to non-labial consonants, they do not volunteer these forms on their own, and they express a strong preference for forms where the rule does not apply to these segments. This is why I have formulated the rule in (8) as applying only to labials. At present I do not have an explanation for the discrepancy between Dolphyne's data and my own except to note that, as Dolphyne points out (2006: 142), the nasalization rule does not apply at all in Fante. Perhaps the rule is in the process of being lost from Asante Twi under influence from Fante (though this would not explain why it still applies to labials).

In addition to Labial Nasalization, there is a regular rule of Nasal Place Assimilation, shown below, where a nasal consonant takes on the place of articulation of a following consonant (9). Via the application of Nasal Place Assimilation plus Labial Nasalization, $/ \mathrm{n}+\mathrm{b} /$ sequences surface as [mm], as in mì ̀̀-mìsá àsèm 'I don't ask something' from /mì ǹ-bìsá àsèm/.

Nasal Place Assimilation

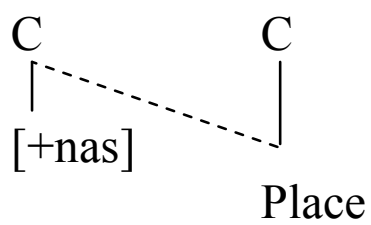

A final rule exhibited in the negative habitual forms above (examples (6)a, b, e, and f) is Tonal Plateauing, by which a L-toned mora surfaces with a downstepped $\mathrm{H}$ tone between two H-toned moras. This is seen, for example, in wó 'j-'káé kòfi 'you don't remember Kofi', where the verb, which underlyingly has a LH tone pattern, surfaces with the tone pattern 'HH. The rule is schematized in (10).

(10) Tonal Plateauing

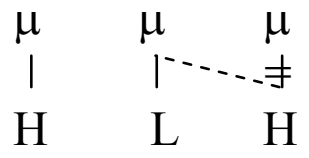


There are a few complications to the Tonal Plateauing rule that need to be addressed here. The first is that, as mentioned earlier, this rule must be preceded by Nasal Tone Assimilation. In addition, it must be assumed that the tone that is dislodged by Nasal Tone Assimilation is deleted or fused with a following identical (linked) tone, and that this also takes place before Tonal Plateauing. The derivation of the form wó 'y-'káé kòfi below shows how the processes interact.

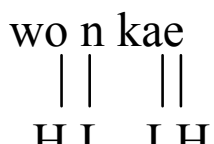

wó ý-'káé kòfi 'You don't remember Kofi.'

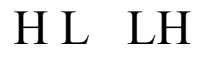

Nasal Tone Assimilation

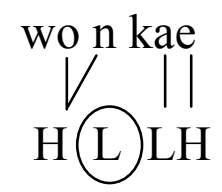

Floating $L$ is deleted before a linked $L$

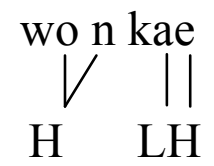

Tonal Plateauing

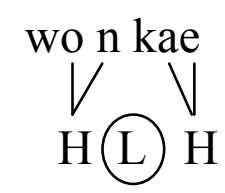

Notice that Nasal Tone Assimilation, and the deletion of the floating L before the linked L, feed Tonal Plateauing; if the L of the $/ \grave{n}$-/ prefix were still present when Tonal Plateauing applied, the rule would be blocked. The same is true in (6)f.

Another complication is that Tonal Plateauing does not apply to verbs of the CVR(V) LH type (e.g., dane 'turn') as can be seen in (6)c above. However, this does not require any modification to Tonal Plateauing if we assume (following, e.g., Ofori 2006a) that the underlying form of verbs of this type does not contain the final vowel. This would mean that the $\mathrm{H}$ tone of the verb is floating, and therefore the representation of the verb would not meet the structural requirement for the application of Tonal Plateauing. Under this 
analysis, the root-final vowel would have to be inserted by default at the end of the derivation.

A third complication is that there are some tense/aspect categories in which Tonal Plateauing does not apply where it would be expected to apply given the description of the rule in (10). First, it does not apply in habitual, or in the past (to be discussed below). The non-application of Tonal Plateauing in the habitual must be treated as an arbitrary fact about the habitual since there is no phonological element of this aspect category that would explain the failure of the rule.

It should also be noted that the Tonal Plateauing process observed in my data differs from the process described by Dolphyne (2006). Dolphyne proposed a Tone Spreading rule by which the underlying sequence HLH surfaces as $\left[\mathrm{HH}^{\prime} \mathrm{H}\right]$ when the onset of the third syllable is an obstruent; otherwise HLH surfaces as $\left[\mathrm{H}^{\prime} \mathrm{HH}\right]$ (2006: 60). In my data from KD and EA I have not found evidence for any underlying HLH sequences surfacing as $\left[\mathrm{HH}^{!} \mathrm{H}\right]$ except in cases where the $\mathrm{L}$ tone belongs to the negative nasal prefix. In all of my examples, if Tonal Plateauing applies, the output is $\left[\mathrm{H}^{\prime} \mathrm{HH}\right]$, indicating that the spread of the $\mathrm{H}$ tone is always from right to left, never left to right.

We turn now to another tense category in which the verb root is not marked by a grammatical tone: the future. As seen in the examples below, future is marked by the prefix /bz-/.

\section{a. $\mathrm{CV} \mathrm{H}$}

$$
\begin{aligned}
& \text { ésí bé-tó pèn } \\
& \text { wó bé-tó pèn } \\
& \text { yàw bé-tó pèn } \\
& \text { ò bé-tó pèn }
\end{aligned}
$$

\footnotetext{
${ }^{4}$ The 1 sg subject and future tense are marked by a single portmanteau morpheme, /mé-/. Note that this does not reduce to $/ \mathrm{mI}+$ bé/, because there is no regular phonological process that deletes $/ \mathrm{I} /$ between $/ \mathrm{m} /$ and $/ \mathrm{b} /$, and the output of Labial Nasalization is [mm], not [m].
} 
b. CVR(V) HL
ésí bé-nôm ìnsyù
'Esi will drink water.'
wó bé-nôm ìnsyù
'You will drink water.'
yàw bé-nôm ìnsyù
'Yaw will drink water.'
mé-nôm ìnsyù
'I will drink water.'

c. CVR(V) LH
ésí bé-dàné nè hộ
'Esi will turn herself.'
mó bé-dàné mò hô
'You pl. will turn yourselves.'

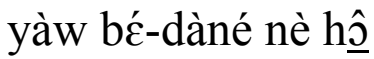
'Yaw will turn himself.'
ว̀ bé-dàné nè hộ
'He will turn himself.'

d. CGV LH $(/ \mathrm{CVV} /)^{5}$
ésí bé-'bwá yàà
'Esi will help Yaa.'
wó bé-'bwá yàà
'You will help Yaa.'
yàw bé-'bwá yàà
'Yaw will help Yaa'
j bé-'bwá yàà
'He will help Yaa.'

e. CVV LH
ésí bé-'káé kòfî
'Esi will remember Kofi.'
wó bé-'káé kòfî
'You will remember Kofi.'
yàw bé-'káé kòfî
'Yaw will remember Kofi.'
mé'-káé kòfî
'I will remember Kofi.'

\footnotetext{
${ }^{5}$ The downstep in the forms in (d) is the surface manifestation of the floating $L$ tone that is left behind when the first mora of the root is deleted via the Glide Formation rule described earlier.
} 


\section{f. CVOV LH}

$\begin{array}{ll}\begin{array}{l}\text { ésí bé-'bísá àsèm } \\ \text { mó bé-'bísá àsèm }\end{array} & \begin{array}{l}\text { 'Esi will ask something.' } \\ \text { 'You pl. will ask something.' }\end{array} \\ \begin{array}{ll}\text { yàw bé-'bísá àsèm } \\ \text { ò bé-'bísá àsèm }\end{array} & \text { 'Yaw will ask something.' } \\ \text { 'He will ask something.' }\end{array}$

Recall from the earlier discussion that Dolphyne (2006) claims that Tone Spreading (here, 'Tonal Plateauing') is rightward when the onset of the third syllable is an obstruent. This means that, for example, the future forms of the verb 'ask' should exhibit righward H tone spreading; indeed, Dolphyne transcribes 'he will ask' as [ò bé-bí'sá]. In KD and EA's pronunciation, however, the downstep occurs between the first and second syllables in the underlying HLH sequence, i.e., [ò bé-'bísá]. Below is a spectrogram and pitch track showing KD's pronunciation of 'Esi will ask something', showing that the downstep occurs on the first syllable of the verb root rather than the second.

$$
\text { ésí bé-'bísá àsèm Esi will ask something.' }
$$

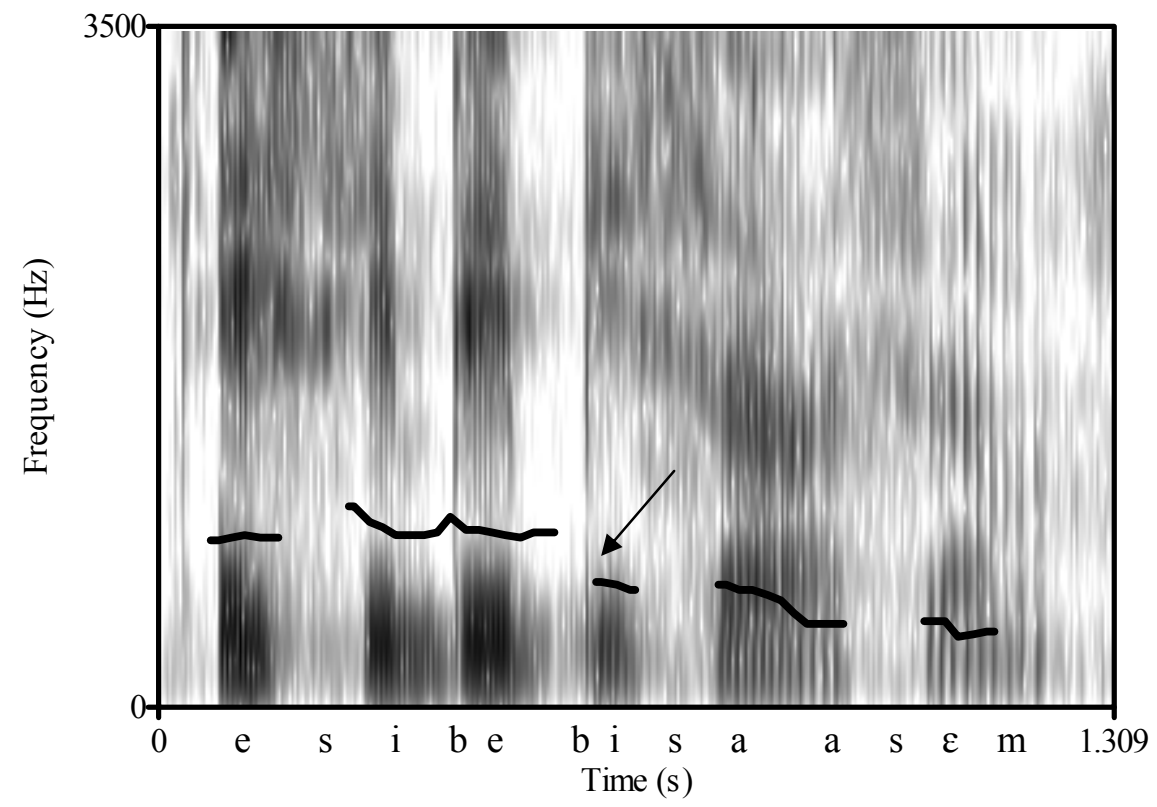

As seen in (14), the negative future does not assign a tone to the verb root, but it does come with a prefix tone that affects the tone of some subject markers (to be discussed below). Like other negative categories such as the negative habitual described above, the negative future is marked with the negative prefix /ǹ-/. In addition, however, the negative future has a floating $\mathrm{H}$ tone that 
immediately precedes the negative /ǹ-/ marker. The regular (affirmative) future marker /bź-/ is absent in the negative future, so the floating $\mathrm{H}$ tone prefix marks both future and negative.

a. $\mathrm{CV} \mathrm{H}$
ésí ń-'tó pèn
'Esi will not buy a pen.'
wó ń-'tó pèn
'You will not buy a pen.'
yàw ńń' tó pèn
'Yaw will not buy a pen.'
yé ń-'tó pèn
'We will not buy a pen.'

b. CVR(V) HL

ésí ń-'nôm ìnsyù

wó ń-'nôm ìnsyù

yàw ńń-'nôm ìnsyù

ว́n n'-nôm ìnsyù

c. $\mathrm{CVR}(\mathrm{V}) \mathrm{LH}$

ésí ń-dàné nè hô ómó ń-dàné òmò ĥ̂

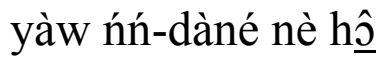
yé ń-dàné yè hộ

\section{d. CGV LH (/CVV/)}

ésí ín-'mwá yàà mó ḿ-'mwá yàà

yàw ḿm-'mwá yàà mí ḿ-'mwá yàà
'Esi will not drink water.' 'you will not drink water.'

'Yaw will not drink water.' 'He will not drink water.'
'Esi will not turn herself.'

'They will not turn themselves.'

'Yaw will not turn himself.'

'We will not turn ourselves.'
'Esi will not help Yaa.'

'You pl. will not help Yaa.'

'Yaw will not help Yaa.'

'I will not help Yaa.' 
e. CVV LH
ésí ý-'káé kòfî
'Esi will not remember Kofi.'
wó ý-'káé kòfî
'You will not remember Kofi.'
yàw ýń-'káé kòfî
'Yaw will not remember Kofi.'
yé ń-'káé kòfî
'We will not remember Kofi.'

\section{f. CVOV LH}
ésí ḿ-'mísá àsèm
'Esi will not ask something.'
mó ḿ-'mísá àsèm
'You pl. will not ask something.'
yàw mím-'mísá àsèm
'Yaw will not ask something.'
ó ḿ-'mísá àsèm
'He will not ask something.'

The floating $\mathrm{H}$ tone that I propose behaves differently depending on the surrounding tones. If the subject has a final $\mathrm{H}$ tone, the floating $\mathrm{H}$ is deleted or absorbed, leaving no trace. If the subject has a final L tone, the behavior of the floating $\mathrm{H}$ depends on the status of the subject: if subject is a pronoun, the $\mathrm{H}$ tone links to the subject, changing its tone. If, on the other hand, the subject is a noun (e.g., a person's name), the H tone associates to the nasal consonant of the negative prefix.

The derivation of negative future forms in each context is given below. First, (15) shows what happens to a form where the subject has an underlying final $\mathrm{H}$ tone: the floating $\mathrm{H}$ is deleted or absorbed, and then Nasal Tone Assimilation applies.

H-toned subject

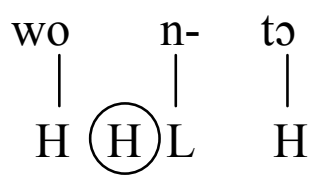

wó ń-'tó pèn 'You will not buy a pen.'

Floating $H$ deleted/absorbed after $H$

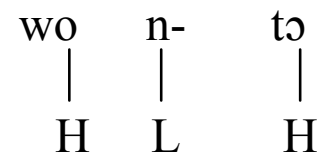




\section{Nasal Tone Assimilation}

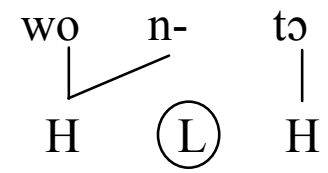

(16) shows the derivation of a form in which the subject is a L-toned pronoun. The floating $\mathrm{H}$ tone associates to the subject, causing it to surface with $\mathrm{H}$ tone. Nasal Tone Assimilation then applies, resulting in a downstepped $\mathrm{H}$ tone on the nasal prefix.

(16) L-toned pronoun subject

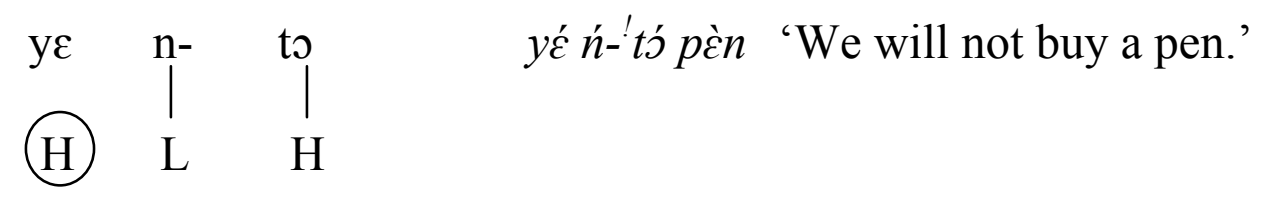

Floating H links to subject

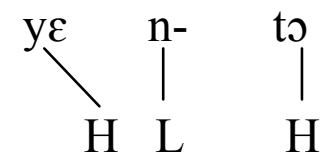

Nasal Tone Assimilation

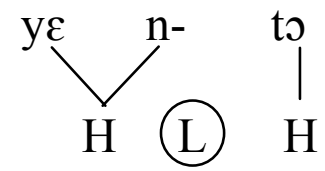

Finally, (17) shows the derivation of a form where the subject is a person's name with an underlying final $\mathrm{L}$ tone. The floating $\mathrm{H}$ tone prefix associates to the $/ \mathrm{n} /$ of the negative prefix, resulting in a falling tone, which causes lengthening of the nasal. Then Nasal Tone Assimilation applies, resulting in a $\mathrm{HH}$ tone pattern on the lengthened nasal prefix.

(17) L-toned subject (name)

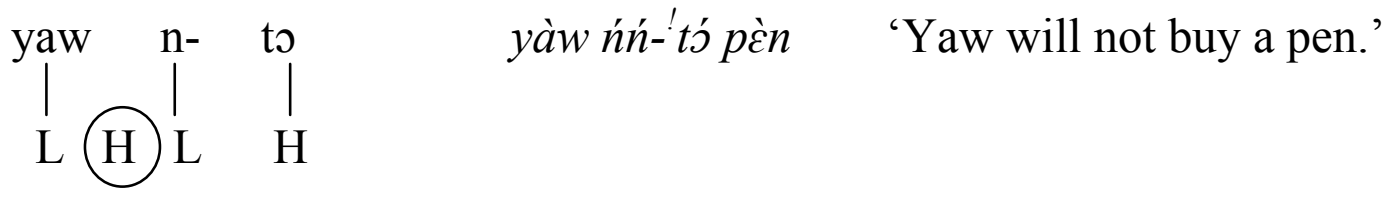


Floating H links to nasal

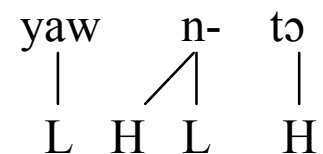

Nasal is lengthened due to falling tone

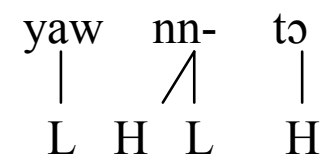

Nasal Tone Assimilation

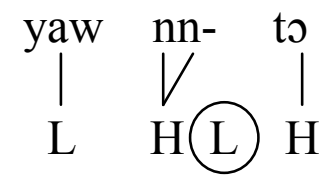

Why does the floating $\mathrm{H}$ associate to pronouns but not to L-toned nouns in subject position? There are a number of possible explanations. One is that Ltoned nouns have underlying $\mathrm{L}$ tones while the 'L-toned' pronoun subjects are really toneless and get their surface L tones by default. Notice that this is the approach I have taken above. One benefit to this approach is that it allows us to avoid having to propose another rule deleting the underlying $\mathrm{L}$ of the pronoun (since otherwise an underlying L-toned pronoun with a floating $\mathrm{H}$ tone associated to it from the right should yield a rising tone rather than a level $\mathrm{H}$ tone). Such a rule would have to be specific to the subject markers, since rising tones are allowed to occur elsewhere in the language. Another possibility is that there is a restriction on $\mathrm{H}$ tone association such that the floating $\mathrm{H}$ will only associate to something within the same word, assuming (following, e.g., Dolphyne 2006) that pronoun subjects are prefixes and therefore contained within the word.

The negative past is marked by a prefix /a-/, which always has the same tone as the final tone of the subject, followed by the negative prefix /ǹ-/. Examples are given in (18). 
(18) a. $\mathrm{CV} \mathrm{H}$
ésí á-ń-'tó pèn
wá-ń-'tó pèn
'Esi didn't buy a pen.'
'You didn't buy a pen.'
yàw à-ǹ-tó pèn
'Yaw didn't buy a pen.'
yà-ǹ-tó pèn
'We didn't buy a pen.'

b. $\mathrm{CVR}(\mathrm{V}) \mathrm{HL}$

ésí á-ń-'nôm ìnsyù mwá-ń-'nôm ìnsyù

yàw à-ǹ-nôm ìnsyù wà-ǹ-nôm ìnsyù

c. CVR(V) LH

ésí á-ń-dàné nè hô wá-ń-dàné wò hô

yàw à-ǹ-dàné nè hô̂ mà-ǹ-dàné mì hô

\section{d. CGV LH (/CVV/)}

ésí á-ḿ-'mwá yàà wá-ḿ-'mwá yàà

yàw à-m̀-mwá yàà mà-m̀-mwá yàà

e. CVV LH
'Esi didn't drink water.'

'You pl. didn't drink water.'

'Yaw didn't drink water.'

'He didn't drink water.'
'Esi didn't turn herself.'

'You didn't turn yourself.'

'Yaw didn't turn himself.'

'I didn't turn myself.' ésí á-ń-'káé kòfì wá-ń-'káé kòfî

yàw à-ỳ-kàé kòfî yà-ỳ-kàé kòfî
'Esi didn't help Yaa.'

'You didn't help Yaa.'

'Yaw didn't help Yaa.'

'I didn't help Yaa.'
'Esi didn't remember Kofi.'

'You didn't remember Kofi.'

'Yaw didn't remember Kofi.'

'We didn't remember Kofi.' 


\section{f. CVOV LH}

\begin{tabular}{|c|c|}
\hline $\begin{array}{l}\text { ésí é-ḿ-'mísá àsèm } \\
\text { mwé-ḿ-'mísá àsèm }\end{array}$ & $\begin{array}{l}\text { 'Esi didn't ask something.' } \\
\text { 'You pl. didn't ask something.' }\end{array}$ \\
\hline غ̀m & 'Yaw didn't ask something.' \\
\hline è-m̀-mìsá àsc̀m & 'We didn't ask something.' \\
\hline
\end{tabular}

I analyze the tone pattern of the prefix /a-/ as resulting from the prefix having no underlying tone. It is assigned its tone via the Tone Spreading rule in (19), which spreads a tone rightward onto any toneless mora ( $\mu$ ' represents a toneless mora; note that it is crucial to indicate that the target of spreading is toneless, because tone spreading does not apply to any mora that already bears a tone).

\section{Tone Spreading}

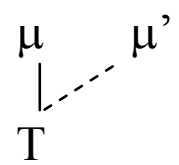

The /a/ also triggers Glide Formation or Vowel Fusion when a vowel precedes it, resulting in predictable surface changes to subject pronouns as exhibited in the data above.

A final tense/aspect category that is not marked by a grammatical tone on the verb root is the progressive. As shown in (20), progressive forms have a Ltoned prefix consisting of a segment that matches the final segment of the subject.

a. $\mathrm{CV} \mathrm{H}$

$$
\begin{aligned}
& \text { ésí 'í-tó pèn } \\
& \text { ómó !ó-tó pèn } \\
& \text { yàw ì-tó pèn } \\
& \text { mì Ì-tó pèn }
\end{aligned}
$$

$$
\begin{aligned}
& \text { 'Esi is buying a pen.' } \\
& \text { 'They are buying a pen.' } \\
& \text { 'Yaw is buying a pen.' } \\
& \text { 'I am buying a pen.' }
\end{aligned}
$$

\footnotetext{
${ }^{6}$ Note that this and other progressive examples involving the subject 'Yaw' are transcribed as having a L-toned syllabic glide preceding the verb root. Syllabic, tone-bearing glides are not attested elsewhere in the data, so the proper phonological representation of these segments may therefore be a vowel rather than a glide, as in, e.g., yàw ̀̀-tó pèn. I have transcribed the prefixes as glides here in order to reflect their auditory profile, and to reflect more clearly the fact that they result from a lengthening of the immediately preceding segment.
} 
b. CVR(V) HL
ésí 'í-nôm ìnsyù
'Esi is drinking water.'
wó 'ó-nôm ìnsyù
'You are drinking water.'
yàw ẁ-nôm ìnsyù
'Yaw is drinking water.'
ว̀ j̀-nôm ìnsyù
'He is drinking water.'

c. $\mathrm{CVR}(\mathrm{V}) \mathrm{LH}$

ésí ì-dàné nè hô

wó ò-dàné wò hô

yàw ẁ-dàné nè hô

mì Ì-dàné mì hô
'Esi is turning herself.'

'You are turning yourself.'

'Yaw is turning himself.'

'I am turning myself.'

d. CGV LH (/CVV/)

ésí ì-bwá yàà

ómó ò-bwá yàà

yàw ẁ-bwá yàà

mì ì-bwá yàà
'Esi is helping Yaa.'

'They are helping Yaa.'

'Yaw is helping Yaa.'

'I am helping Yaa.'

e. CVV LH

ésí ì-kàé kòfî

wó ò-kàé kòfî

yàw ẁ-kàé kòfî

mì ì-kàé kòfî
'Esi is remembering Kofi.'

'You are remembering Kofi.'

'Yaw is remembering Kofi.'

'I am remembering Kofi.'

\section{f. CVOV LH}

ésí ì-bìsá àsèm wó ò-bìsá àsèm

yàw ẁ-bìsá àsèm

mì ì-bìsá àsèm
'Esi is asking something.'

'You are asking something.'

'Yaw is asking something.'

'I am asking something.' 
The progressive appears to differ across dialects. Dolphyne (2006) states that the prefix [rغ̀-] is used in Asante, but my consultants instead produce the forms in (20), and they claim that the [rغ̀-] form is the Akuapem pronunciation. It is also spelled $<$ re- $>$ in the Akan orthography. My analysis of the form produced by my consultants is that the progressive prefix consists of a single L-toned mora. Because the mora is not underlyingly associated with any segmental features, it takes on the quality of whatever segment precedes it via a rule that spreads the entire segment's Root node (i.e., the node in the feature geometry that dominates all of the segment's features) to the empty mora, whether the segment is a consonant or a vowel. The rule is schematized in (21).

Root Node Spreading

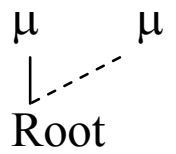

As will be discussed below, this analysis of the progressive as being marked by an empty mora affix is very similar to (and also bears on) Ofori's $(2006 a, b)$ analysis of the past suffix.

3.2 Categories marked by $L$ tone on the verb root. There is one tense/aspect category that I analyze as being marked by a L tone on the verb root, namely, past. As shown in (22), past forms have a L tone on the first mora of the root, and when an object is present, the final segment of the verb root is lengthened, with a $\mathrm{L}$ tone occurring on the latter portion of the lengthened segment.
a. $\mathrm{CV} \mathrm{H}$

$$
\begin{aligned}
& \text { ésí tò-ò pèn } \\
& \text { wó tò-ò pèn } \\
& \text { yàw tò-j̀ pèn } \\
& \text { ò tò-ว̀ pèn }
\end{aligned}
$$

'Esi bought a pen.'

'You bought a pen.'

'Yaw bought a pen.'

'He bought a pen.' 
b. CVR(V) HL

ésí nòm-m̀ ìnsyù wó nòm-m̀ ìnsyù

yàw nòm-m̀ ìnsyù j̀ nòm-m̀ ìnsyù

c. CVR(V) LH

ésí dàné-è nè hô wó dàné-è wò hô

yàw dàné-è nè hô mì dàné-è mì hô

\section{d. CGV LH (/CVV/)}

ésí bòá-à yàà wó bòá-à yàà

yàw bòá-à yàà

yè bòá-à yàà

e. CVV LH

ésí kàé-è kòfî

wó kàé-è kòfî

yàw kàé-è kòfî

mì kàé-è kòfî
'Esi drank water.' 'you drank water.'

'Yaw drank water.'

'He drank water.'

'Esi turned herself.'

'You turned yourself.'

'Yaw turned himself.'

'I turned myself.'

'Esi helped Yaa.'

'You helped Yaa.'

'Yaw helped Yaa.'

'We helped Yaa.'

'Esi remembered Kofi.'

'You remembered Kofi.'

'Yaw remembered Kofi.'

'I remembered Kofi.'

\section{f. CVOV LH}

ésí bìsá-à àsc̀m

wó bìsá-à àsèm

yàw bìsá-à àsèm

mì bìsá-à àsèm
'Esi asked something.'

'You asked something.'

'Yaw asked something.'

'I asked something.' 
Following Ofori (2006a,b), I analyze the lengthening of the final segment as an empty mora suffix. The suffix takes on the quality of the vowel or consonant to its left via the Root Node Spreading rule described earlier. The past suffix therefore has the same phonological representation as the progressive prefix in my analysis, namely an empty mora linked to a L tone. ${ }^{7}$

When no object follows the verb, the ending $y \grave{\varepsilon} \sim \grave{I y} \dot{\varepsilon} \sim \grave{\partial y} \hat{\varepsilon}$ appears along with the lengthening of the final segment shown above. Examples are given below.
wó tò̀̀yè 'You bought.'
wó nòmùyè 'You drank.'
wó dànéèyè 'You turned.'
wó bòáàyè ' 'You helped.'
wó kàéèyè 'You remembered.'
wó bìsáàyè 'You asked.'

Ofori (2006a: 38-44) gives a number of arguments that the source of this ending is not an alternative past tense suffix $-y \hat{\varepsilon}$ as was proposed by Dolphyne (2006). Ofori's analysis is that the empty mora of the past suffix becomes /I/ when no object follows the verb, and then the segment $/ \varepsilon /$ is inserted after the $/ \mathrm{I} /$ for reasons of phonological augmentation. The /I/ changes to [y] by Glide Formation, and its mora is preserved via lengthening of the root-final vowel. If the root is consonant-final, a high vowel is inserted after the root (this vowel surfaces as round when the final consonant is labial) before the past suffix. Ofori's rationale for assuming that there is an /I/ at some point in the derivation appears to be the fact that in other dialects of Akan (i.e., Fante and Akuapem), verbs in this context end in $-I$ rather than having a lengthened final vowel followed by $-y \grave{\varepsilon}$. This may well be the historical origin of the $-y \grave{\varepsilon}$ ending, but modern Asante lacks evidence for the $-I$ suffix. I therefore propose that the empty mora suffix is realized on all past affirmative forms (whether followed by an object or not) as lengthening of the root-final segment, and that there is a separate element $-y \grave{\varepsilon}$ that is deleted when an object follows the verb.

\footnotetext{
${ }^{7}$ Stump gives an alternative analysis of the past suffix as /-a/, claiming (2009: 223) in response to Ofori (2006a) that '...there is no independent motivation for the postulation of floating moras in this language'. However, representing the suffix as /-a/ does not allow for a satisfactory explanation of why the suffix always assimilates to the final segment of the verb root regardless of whether it is a consonant or a vowel. There is no independent process in the language (or, most likely, in any language) that changes /a/ into whatever consonant or vowel precedes it, so one would have to posit an item-specific rule of total assimilation that applies only to the suffix /-a/. It appears that Stump chose /-a/ as the suffix simply because the examples he used involved the verb bisa 'ask', which ends in /a/; his analysis fails when verbs not ending in /a/ are taken into account.
} 
Evidence for the floating $\mathrm{L}$ tone prefix in the past comes from the fact that verb roots having initial $\mathrm{H}$ tone in other forms have initial $\mathrm{L}$ tone in the past (e.g., the verb 'bring' in (22)a). This change can be explained by a floating L prefix that associates to the left edge of the verb root via a rule of Grammatical Tone Association (24), replacing the lexical root-initial tone. ${ }^{8}$

Grammatical Tone Association

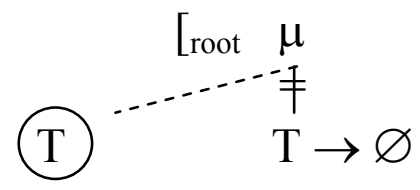

The floating L prefix may also have an indirect effect, in cases where the verb root has underlying initial L tone, precluding a distinct realization of the floating L on the root. In those cases, Glide Formation fails to apply, a fact that could be attributed to the $\mathrm{L}$ tone of the past. Notice that the forms of the verb boa 'help' in (22)d do not exhibit Glide Formation. Recall that this same verb does undergo Glide Formation in habitual forms such as wó 'bwá yàà 'you help Yaa' in (1)d. It is possible that the rule simply does not apply in this tense. However, it is also possible that Glide Formation is reversed via a rule of Glide Vocalization when the mora that is delinked from the vowel is associated to a $\mathrm{L}$ tone marking the past tense. The data do not distinguish between these two possibilities at present, so this is only a hypothetical manifestation of the floating L. It is true that none of the forms in (22) exhibit the Tonal Plateauing rule, but since another tense/aspect category (habitual) is already marked as not undergoing this rule, the failure of the rule to apply in the past is not necessarily attributable to the presence of the floating $L$ and therefore does not provide strong evidence for it.

\footnotetext{
${ }^{8}$ Though this rule is similar to the Tone Spreading rule proposed above and can be assumed to apply at roughly the same point in the derivation, the two rules differ in that Grammatical Tone Association replaces the tone on the mora to which it links, while Tone Spreading applies only to toneless moras.
} 
3.3 Categories marked by $\mathbf{H}$ tone. The perfect and negative perfect are marked by a $\mathrm{H}$ tone on the first mora of the verb root. Perfect (affirmative) forms are given in (25). As can be seen in the data, in addition to the tone changes (to be discussed further below), the perfect also has a prefix /a-/, which always surfaces with the same tone as the final tone of the subject. ${ }^{9}$

a. $\mathrm{CV} \mathrm{H}$
ésí á-tò pèn
'Esi has bought a pen.'
wá-tò pèn
'You have bought a pen.'
yàw à-tó pèn
'Yaw has bought a pen.'
wà-tó pèn
'He has bought a pen.'

b. CVR(V) HL
ésí á-nòm ìnsyù
'Esi has drunk water.'
wá-nòm ìnsyù
'You have drunk water.'
yàw à-nôm ìnsyù
'Yaw has drunk water.'
mà-nôm ìnsyù
'I have drunk water.'

c. $\mathrm{CVR}(\mathrm{V}) \mathrm{LH}$

ésí á-dàné nè hô

mwá-dàné mò hô

yàw à-dáné nè hô

wà-dáné nè hô
'Esi has turned herself.'

'You pl. have turned yourself.'

'Yaw has turned himself.'

'He has turned himself.'

d. CGV LH (/CVV/)

ésí á-'bwá yàà

wá-'bwá yàà

yàw à-bwá yàà

mà-bwá yàà
'Esi has helped Yaa.'

'You have helped Yaa.'

'Yaw has helped Yaa.'

'I have helped Yaa.'

\footnotetext{
${ }^{9}$ Notice that this prefix is phonetically identical to the negative past prefix described above.
} The similarity between these two affixes will be discussed in detail in $\S 4$. 
e. CVV LH
ésí á-'káé kòfî
'Esi has remembered Kofi.'
wá-'káé kòfî
'You have remembered Kofi.'
yàw à-káé kòfi
'Yaw has remembered Kofi.'
yà-káé kòfî
'We have remembered Kofi.'

\section{f. CVOV LH}
ésí é-'bísá àsèm
'Esi has asked something.'
wé-'bísá àsèm
'You have asked something.'
yàw è-bísá àsèm
yè-bísá àsèm
'Yaw has asked something.'
'We have asked something.'

I analyze the perfect as having a $\mathrm{H}$ tone prefix that associates to the leftmost mora of the verb root. The clearest evidence for this prefix comes from forms where the subject has final L tone in (25)a-f above. As seen in those examples, verbs that otherwise have an initial $\mathrm{L}$ tone have initial $\mathrm{H}$ in the perfect when the subject is L-toned. Forms where the subject has $\mathrm{H}$ tone are a bit more complicated due to the application of some rules to be described below.

To account for the tone of perfect verbs after H-toned subjects, we need a rule of Perfect Polarity (26), which applies after Tone Spreading and feeds Plateauing. This rule changes a $\mathrm{H}$ to $\mathrm{L}$ when it immediately follows another $\mathrm{H}$ linked to the perfect prefix /a-/.

Perfect Polarity

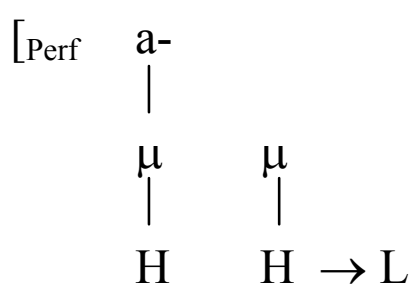

Below is a sample derivation showing perfect forms with a H-toned subject in (27)a and a L-toned subject in (27)b. 
(27) a. H-toned subject

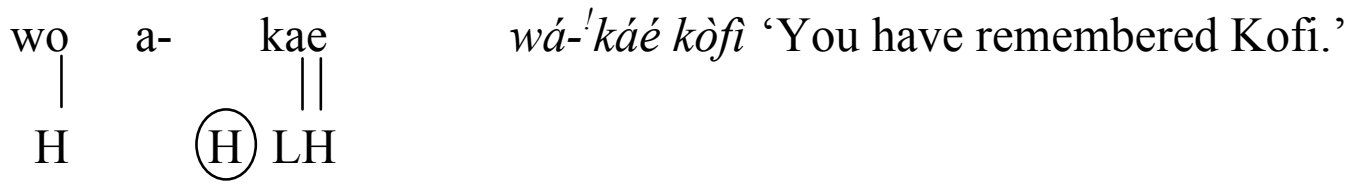

Tone Spreading and Grammatical Tone Association

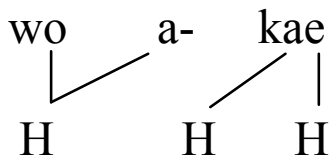

Perfect Polarity

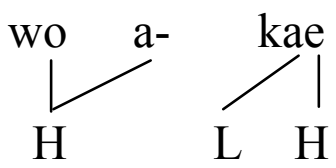

Tonal Plateauing

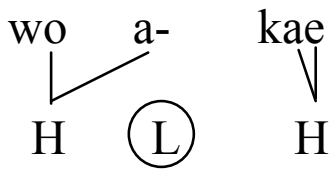

Vowel Fusion

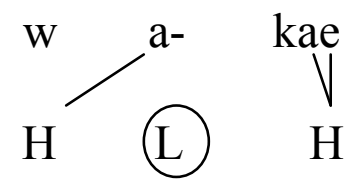

b. L-toned subject

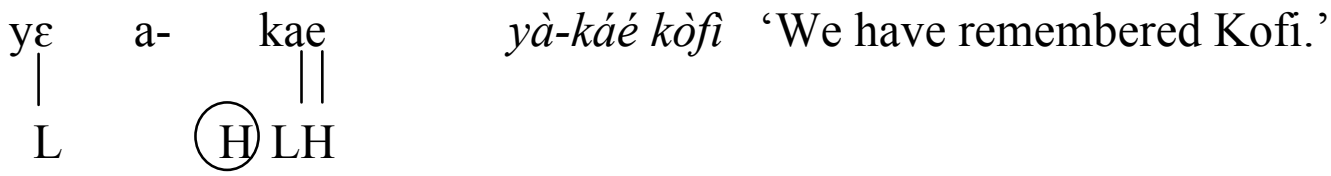


Tone Spreading and Grammatical Tone Association

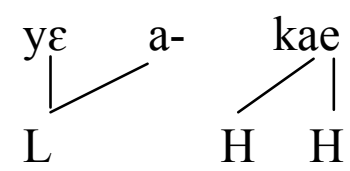

Vowel Fusion

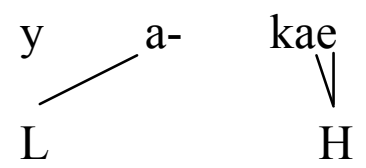

The negative perfect, like the perfect, has a $\mathrm{H}$ tone on the initial mora of the verb root. In addition, negative perfect is marked by the negative prefix /ǹ-/ and by lengthening of the final segment, with $\mathrm{L}$ tone on the lengthened portion of the segment.

a. $\mathrm{CV} \mathrm{H}$

ésí ń-'tó-ò pèn

wó ń-'tó-ò pèn

yàw ǹ-tó-̀̀ pèn

ว̀ ̀̀-tó-ò pèn
'Esi hasn't bought a pen.'

'You haven't bought a pen.'

'Yaw hasn't bought a pen.'

'He hasn't bought a pen.'

b. CVR(V) HL

ésí ń-'nôm-m̀ ìnsyù wó ń-'nôm-m̀ ìnsyù

yàw ǹ-nôm-m̀ ìnsyù

ว̀ ǹ-nôm-m̀ ìnsyù
'Esi hasn't drunk water.'

'You haven't drunk water.'

'Yaw hasn't drunk water.'

'He hasn't drunk water.'

\section{c. CVR(V) LH}

ésí ń-'dáné-è nè hô

wó ń-'dáné-è wò hô

yàw ǹ-dáné-è nè hô

mì ǹ-dáné-è mì hô
'Esi hasn't turned herself.'

'You haven't turned yourself.'

'Yaw hasn't turned himself.'

'I haven't turned myself.' 


\section{d. CGV LH (/CVV/)}
ésí ḿ-'mwá-à yàà
'Esi hasn't helped Yaa.'
wó ḿ-'mwá-à yàà
'You haven't helped Yaa.'
yàw m̀-mwá-à yàà
'Yaw hasn't helped Yaa.'
yè m̀-mwá-à yàà
'We haven't helped Yaa.'

e. CVV LH
ésí ń-'káé-è kòfî
'Esi hasn't remembered Kofi.'
wó ý-'káé-è kòfî
'You haven't remembered Kofi.'
yàw ì-káé-è kòfì
'Yaw hasn't remembered Kofi.'
mì ỳ-káé-è kòfì
'I haven't remembered Kofi.'

\section{f. CVOV LH}
ésí ḿ-'mísá-à àsèm
'Esi hasn't asked something.'
mú ḿ-'mísá-à àsc̀m
'You pl. haven't asked something.'
yàw m̀-mísá-à àsèm
'Yaw hasn't asked something.'
mì m̀-mísá-à àsèm
'I haven't asked something.'

I treat the lengthening of the root-final segment as resulting from a mora suffix, whose phonological representation and behavior are identical to that of the past suffix described earlier. Therefore all of the arguments cited earlier in favor of a mora as the underlying representation of the past suffix also apply here. The similarity between the past and negative perfect has been the subject of some debate in the literature and will be discussed in depth in the following section.

3.4 Interim summary. Having presented all of the verbal categories necessary to exemplify the phonological rules that apply to verbs in Asante Twi, I will now summarize the verbal morphemes and phonological rules before moving on to discuss some important issues arising in the analysis of the verbal morphology. Below is a list of the verbal affixes covered in this paper (see the Appendix for data from categories listed here that were not discussed above; these are marked below with a pound sign). 


\begin{tabular}{|c|c|c|c|}
\hline Category & Marker(s) & Example & $\underline{\text { Gloss }}$ \\
\hline Habitual & $\varnothing$ & ò bìsá & 'he asks...' \\
\hline Negative (e.g. habitual) & $/ \mathrm{n}-/$ & ò m̀-mìsá & 'he doesn't ask...' \\
\hline Future & /bé-/ & ò bé-'bísá & 'he will ask...' \\
\hline Negative future & floating $H$ prefix + neg pfx & ó ḿ-'mísá & 'he will not ask...' \\
\hline Progressive & L mora pfx & ò ò-bìsá & 'he's asking...' \\
\hline \#Negative progressive & identical to neg fut ${ }^{10}$ & ó ḿ-'mísá & 'he isn't asking...' \\
\hline \#Immediate future & $\operatorname{prog} \mathrm{pfx}+/ \mathrm{b} \dot{\varepsilon}-/$ & ò ò-bè-bìsá & 'he's about to ask...' \\
\hline Past & floating $L \mathrm{pfx}+\mathrm{L}$ mora $s f x$ & ò bìsá-à & 'he asked...' \\
\hline Negative past & $/ a-/+$ neg pfx & wè-m̀-mìsá & 'he didn't ask...' \\
\hline Perfect & /a-/ + floating $\mathrm{H}$ pfx & wè-bísá & 'he has asked...' \\
\hline $\begin{array}{l}\text { Negative perfect } \\
\text { \#Imperative }\end{array}$ & $\begin{array}{l}\text { neg pf } x+H \text { pf } x+L \text { mora sf } \\
\text { floating } L\end{array}$ & ò m̀-mísá-à & 'he hasn't asked...' \\
\hline & (replaces lexical tones & $\begin{array}{l}\text { ) bìsà } \\
\text { mé ṕn-mìń }\end{array}$ & 'ask...!' \\
\hline \#Negative imperative & 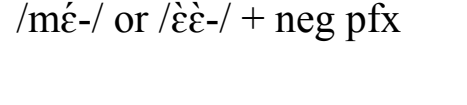 & $\begin{array}{l}\text { mé-ḿ-mìsá } ~ \\
\text { èè-ṁ-mìsá }\end{array}$ & 'don't ask...!' \\
\hline \#Motional & & & \\
\hline $\begin{array}{l}\text { 'come and X' } \\
\text { \#Motional }\end{array}$ & /bè-l/ & ò bè-bìsá-à & 'he came and asked' \\
\hline 'go and X' & /k̀̀-/ & ò kò-bìsá-à & 'he went and asked...' \\
\hline
\end{tabular}

(30) gives a list of phonological rules applying in the data presented in this section. Arrows indicate crucial rule orderings; other rules are not crucially ordered.

(30) Glide Formation

Vowel Fusion

ATR Harmony

Labial Nasalization

Nasal Place Assimilation

Root Node Spreading

Grammatical Tone Association/

Tone Spreading $R$

Perfect Polarity

$\checkmark$ Nonal Tone Assimilation

Final Lowering

${ }^{10}$ This describes speaker EA's pronunciation. Speaker KD's negative progressive forms are less consistent, and he reports not having any negative progressive forms at all for certain verbs. 
In the following section I discuss some theoretical issues arising in the analysis of the verbal morphology, particularly with respect to the past and perfect categories and their negative forms.

\section{Theoretical issues in the interaction of tense/aspect and negation}

The quote from Stump (2009) below summarizes a generalization that has commonly been made about Akan/Twi morphology:

In Twi, negative verb forms exhibit an apparent reversal in tense morphology: the tense morphology of negative past-tense forms is that of affirmative perfect-tense forms, and that of negative perfect-tense forms is that of affirmative past-tense forms (mè-bisá-è 'I asked', $m$-à-bísá 'I have asked', but

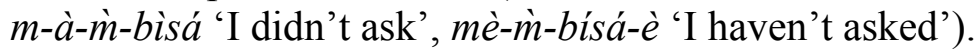

Similarly, Schachter and Fromkin (1968: 126) claim that 'In the presence of the NEGative morpheme, transformational rules apply which replace deep-structure PAS[t] by surface-structure PER[fect], and vice versa.' Dolphyne (1996: 93) describes the pattern as follows: 'The affixes of the Past and Perfect forms of the verb switch over between the positive and negative forms of the verb.' Essilfie (1986: 70) states that 'the Akan negative Past tense form translates the English Negative Perfect tense form while the Akan negative Perfect form translates the English negative Past form.' Similarly, in Saah's (1994: 21) description, a negative past form exhibits 'perfective morphology' while a negative perfect form 'bears the past tense morphology.' Finally, Ofori (2006b: 22) schematizes the situation as follows: 
(31) A Schematic Representation of Similarities in Recent-past and Remotepast Forms $^{11}$

Recent-Past in the Affirmative (Prefix) Recent-past in Negative (Suffix)

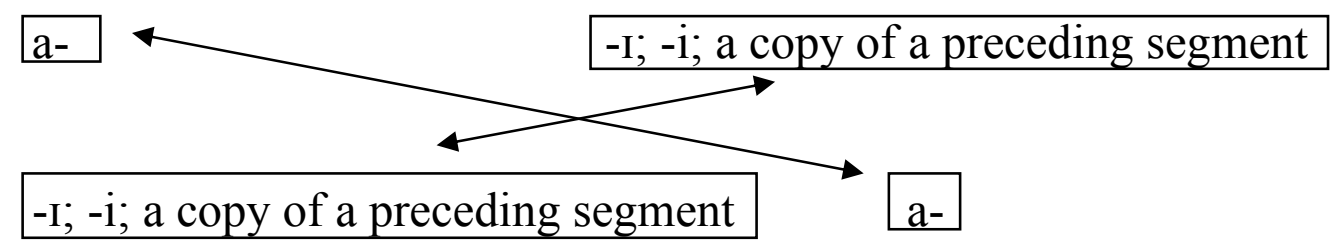

Remote-Past in the Affirmative (Suffix) Remote-past in the Negative (Prefix)

While the sources cited above analyze the pattern as a 'replacement', 'reversal', etc., ${ }^{12}$ Ofori (2006a,b) analyzes all four of the affixes in (31) as having the same underlying form, namely, a single mora. He argues that '...the recent-past morpheme and the remote-past morpheme in Akan each [comprise] a single mora, and these moraic units are not inherently specified as either prefixes or suffixes, but are dependent on a Verbal Affix Hierarchy for their distribution as either prefixes or suffixes. The difference in segmental exponence between prefixal and suffixal position is predictable given certain observations about Akan phonology' (2006b: 22).

Ofori's (2006a,b) analysis is that all of the past and perfect markers reduce to empty mora affixes that are unspecified with respect to the side of the stem to which they attach (i.e., they are 'mobile affixes,' to use Noyer's (1994) term). When these moras occur as prefixes, their default segmental realization is [a] due to 'a general constraint in the language prohibiting non-low vowels initially' (Ofori 2006a: 30). When they are suffixes, they result in lengthening of rootfinal segment (or they surface as $[\mathrm{i} / \mathrm{I}]$, in case no object follows the verb). Ofori (2006a: 25) proposes a Verbal Affix Distribution Hierarchy, reproduced in (32), which accounts for the position of the affixes.

\footnotetext{
${ }^{11}$ Note that what I have been calling perfect is called 'Remote-past' in Ofori's analysis. I use the term 'perfect' because this aspect marking is independent of tense. It can be used in the future, for example: j̀ bé' bá nò ná $\boldsymbol{m}$ à-wó füfû 'By the time he comes, I will have pounded fufu,' where the bolded portion is identical to $m$ à-wó fùfù 'I have pounded fufu.'

12 Osam (1994: 89) uses the term 'criss-crossing', but in his analysis the similarities between the forms are due to historical change and are not explained in the synchronic grammar.
} 
Negative morpheme

Recent-past mora

Remote-past mora (strictly verb-root initial) $>>$

(normally prefixal but must be verb-root edgesharing so suffixing in the negative) $>>$

(normally suffixing, but prefixing in the negative for avoidance of homophony)

The interaction of these constraints results in the perfect marker, which is normally a prefix, becoming a suffix when the negative prefix is present in order to stay adjacent to the root. The past marker, which is normally a suffix, becomes a prefix in the negative in order for the form not to be homophonous with the negative perfect. Once the position of the mora is determined, the quality of the segment associated to it follows from what Ofori argues are regular phonological principles of the language: first, that an empty mora in suffix position will get its segmental features from the root-final segment when an object follows the verb (otherwise it becomes $-I$ or $-i$ by default), and second, that the default realization of a featureless verb-initial mora is [a].

As I have argued above, Ofori's $(2006 \mathrm{a}, \mathrm{b})$ analysis of the past and negative perfect suffixes as empty moras does have significant advantages over alternative analyses, and I have adopted it here. However, other aspects of Ofori's analysis are not compatible with the data I have presented in this paper. There are are at least three major problems with Ofori's account. The first is that, contrary to Ofori's claim, [a] is not the default realization of a verb-initial vowel - at least not in the dialect of Asante Twi under discussion here. Recall that the progressive is marked by a prefixal segment whose features come from the final segment of the subject. I analyzed the progressive prefix as an empty mora, just like the past and negative perfect suffixes, since its behavior is the same (i.e., it exhibits total assimilation to the segment to its left). If this is indeed the correct analysis of the progressive, then we can see that the default realization of a verb-initial vowel is not [a]; rather, when an empty mora precedes the verb, the segmental features are filled in by the same Root Node Spreading rule that supplies segmental features to the past and negative perfect suffixes. Hence, the [a-] prefixes seen in the perfect and negative past cannot be empty moras underlyingly; rather, they must be represented as /a-/.

A second problem for Ofori's account is that the /a-/ prefixes and mora suffixes do not have the same tones. The mora suffixes always have L tone, while the /a-/ prefixes have alternating surface tones. Thus, the mora suffixes are best analyzed as having an underlying $\mathrm{L}$ tone, while the prefixes are underlyingly toneless. Hence they could not all reduce to a single underlying form even in the absence of the vowel quality problem discussed above. 
A third problem is that Ofori's account relies on homophony avoidance. This in itself is problematic a priori only if one accepts arguments made elsewhere against homophony avoidance as a property of synchronic grammars (see, e.g., Lass 1980, Gessner \& Hansson 2004, Blevins \& Wedel 2009, Mondon 2009, Paster to appear ${ }^{13}$ ). But it is especially problematic as an analysis of Asante Twi because the hypothetical homophonous forms that Ofori's analysis is designed to avoid would actually not be truly homophonous in any case, due to the tonal properties of the perfect aspect. Because his analysis ignores tone, Ofori assumes that if the negative past were formed with a suffix rather than a prefix, it would be homophonous with the negative perfect. But as will be shown below, once tone is taken into account, this is shown not to be the case.

To refresh the reader's memory, below are examples representing the four verbal categories of interest (recall that the prefix $a$ - surfaces as [e] with this verb due to ATR harmony).

(33) a. Past

wó bìsá-à àsèm

mì bìsá-à àsèm

b. Perfect

wé-'bísá àsèm

yè-bísá àsèm

c. Negative past

mwé-ḿ-'mísá àsèm yè-m̀-mìsá àsèm
'You asked something.'

'I asked something.'

'You have asked something.'

'We have asked something.'

'You pl. didn't ask something.'

'We didn't ask something.'

\footnotetext{
${ }^{13}$ The references cited here deal primarily with the role of homophony avoidance in blocking sound change rather than in its potential effects in affixation. However, as pointed out by Paster to appear, phonologically driven morphological homophony avoidance would be analyzed using the same anti-homophony mechanisms that have been proposed for phonology, so if it is successfully argued against as a phonological constraint then it should not play a role in morphology either.
} 
d. Negative perfect

mú ḿ-'mísá-à àsèm mì m̀-mísá-à àsèm
'You pl. haven't asked something.'

'I haven't asked something.'

Suppose that the past forms in (33)a above underwent simple negative affixation to form the negative past. We would expect our hypothetical regular negative past forms to be *wó '́m-'mísá-à àsèm 'you didn't ask something' and *mì ìmisá-à àsèm 'I didn't ask something'. Notice that while the form with the pronoun 'you' would be identical to the corresponding negative perfect form in (33)d, the form with 'I' would not be identical to its corresponding negative perfect form; the tone of the verb root differs. This is because, as discussed earlier, the negative perfect (like the perfect) is marked by a $\mathrm{H}$ tone on the first mora of the root. Therefore, an account relying on homophony avoidance to explain why the negative past is formed with a prefix rather than a suffix does not work for all of the data.

A similar problem afflicts Stump's (2009) reanalysis, which is based on data from Dolphyne (2006). Stump proposes two abstract tense categories labeled 'tense ${ }_{1}$ ' and 'tense ${ }_{2}$ '. Tense ${ }_{1}$ is marked by a suffix; tense ${ }_{2}$ is marked by a prefix. There are "rules of semantic interpretation whose construal of the properties "tense ${ }_{1}$ " and "tense $e_{2}$ " in the interpretation of a given verb form is sensitive to whether this form is associated with the property "negative" (Stump 2009: 221). So, a tense ${ }_{1}$ form (i.e., a verb with a lengthened final segment) in the absence of a negative marker (or feature) is interpreted as a past form, while the same verb form in the presence of the negative will be interpreted as a (negative) perfect form. Similarly, a tense ${ }_{2}$ form (i.e., a verb with the prefix $a$-) will be interpreted as a perfect form in the absence of the negative; if the negative is present, the same verb form will be interpreted as a (negative) past form. The problem for such an analysis is that it fails to account for tone. As described above, perfect is consistently marked by a $\mathrm{H}$ tone in both the negative and affirmative forms. Stump acknowledges the tonal complication but explains it away by claiming (as I mentioned earlier in describing the habitual) that some negative forms have the opposite tone from their corresponding affirmative forms (presumably this refers only to the initial tone of the verb root, since we do not observe any tonal alternations on non-initial moras in the root). This claim cannot be refuted by looking at other tense/aspect categories since Stump's claim extends only to 'some' categories, but it is worth reiterating that Stump does claim that there is a tonal reversal between the habitual and negative habitual, and that this claim is incorrect for Asante Twi.

Given that neither Ofori's analysis nor Stump's reanalysis is successful, is there any possible analysis that both accounts for the data and treats the 
similarity between the past/negative perfect suffixes and the perfect/negative past prefixes as significant rather than arbitrary? Of course it is possible to analyze each of these four categories as having its own unique morphology so that, for example, the perfect prefix $a$ - is a distinct formal object from the negative past prefix $a$ - that happens to have the same phonological shape. However, this approach seems unsatisfying in light of the behavior of the past and negative perfect suffixes, since as discussed above, both are analyzable as floating moras and have a $-y \hat{\varepsilon}$ ending that is deleted when an object follows the verb. ${ }^{14}$

I propose a variant on Stump's (2009) analysis where the abstract 'tense ${ }_{1}$ ' vs. 'tense ${ }_{2}$ ' distinction is responsible for the segmental morphology of past and perfect and their respective negative forms, but perfect is also independently marked by a floating $\mathrm{H}$ tone prefix. The effect is that there is some redundancy in the exponence of aspectual features on the verb, since, for example, the presence of the tense ${ }_{2}$ prefix $a$ - in the absence of the negative marker is sufficient to indicate perfect aspect, but this verb will also bear a $\mathrm{H}$ tone on the root-initial mora as another marker of the perfect. Similarly, when the negative marker is present, the tense ${ }_{1}$ mora suffix marks the verb as perfect, but the $\mathrm{H}$ tone on the root-initial mora also indicates perfect aspect.

\section{Conclusion}

In this paper I have described the verbal morphology of Asante Twi. I have shown how the verbal morphology is analyzable as a compositional system in which affixes and their associated meanings combine straightforwardly to produce transparent surface forms, with a few exceptions as noted. I have also proposed an apparently novel analysis of grammatical tone patterns in the verbal morphology that avoids reference to tone classes or lexical groupings. Previous analyses of Asante Twi morphology were discussed, with particular attention to the interaction of tense/aspect and negation, which has featured prominently in the literature. Though future research may produce a superior explanation for

\footnotetext{
14 Osam (1994), rejecting the possibility of a synchronic explanation for these patterns, instead attempts to explain them diachronically. He claims that over time, perfect markers tend to develop into perfective or past markers (following Heine 1993), and that negative forms are more conservative than affirmative forms (following Givón 1979). Based on these generalizations, he suggests a diachronic approach in which an old perfect suffix developed into a completive suffix and a new perfect prefix $a$-; the new perfect and completive had the same negative forms at this stage. After this, 'for some reason currently unclear... the completive developed a new negative form while the perfect maintained the older negative form' (Osam 1994: 94). See Ofori (2006a: 15) for several arguments against Osam's approach.
} 
this complex pattern, I have provided one possible analysis that avoids the shortcomings of previous analyses.

\section{Appendix}

Below are examples of verbs in tense/aspect/mood/polarity categories not presented in the paper.

(34) Immediate future - progressive prefix (a L-toned mora) followed by the prefix /b̀̀-/

a. $\mathrm{CV} \mathrm{H}$

ésí ì-bè-tó pèn

ómó ò-bè-tó pèn

yàw ̀̀-bè-tó pèn

mì Ì-bè-tó pèn
'Esi is about to buy a pen.'

'They are about to buy a pen'

'Yaw is about to buy a pen.'

'I am about to buy a pen.'

b. CVR(V) HL

ésí ì-bè-nôm ìnsyù

wó ò-bè-nôm ìnsyù

yàw ẁ-bc̀-nôm ìnsyù

mì Ì-bè-nôm ìnsyù
'Esi is about to drink water.'

'You are about to drink water.'

'Yaw is about to drink water.'

'I am about to drink water.'

c. $\mathrm{CVR}(\mathrm{V}) \mathrm{LH}$

ésí ì-bè-dàné nè hô $\quad$ 'Esi is about to turn herself.'

wó ò-b̀̀-dàné wò hô $\quad$ 'You are about to turn yourself.'

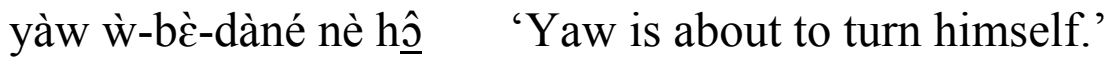

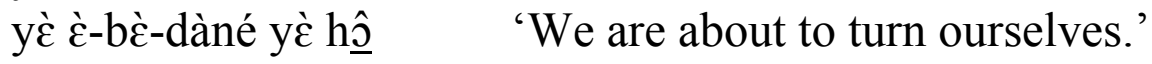


d. CGV LH (/CVV/)

ésí ì-bc̀-bwá yàà

ómó ò-bè-bwá yàà

yàw ì-bè-bwá yàà

mì Ì-bè-bwá yàà
'Esi is about to help Yaa.'

'They are about to help Yaa.'

'Yaw is about to help Yaa.'

'I am about to help Yaa.'

e. CVV LH

ésí ì-bc̀-kàé kòfî

wó ò-bc̀-kàé kòfî

yàw ẁ-bè-kàé kòfì

j̀ j-bè-kàé kòfí
'Esi is about to remember Kofi.'

'You are about to remember Kofi.'

'Yaw is about to remember Kofi.'

'He is about to remember Kofi.'

\section{f. CVOV LH}

ésí ì-bè-bìsá àsèm j̀mó ò-bè-bìsá àsèm

yàw ẁ-bè-bìsá àsèm yè è-bè-bìsá àsèm
'Esi is about to ask something.'

'They are about to ask something.'

'Yaw is about to ask something.'

'We are about to ask something.'

(35) Imperative (sg.) - floating L tone associates to every mora of the root, eliminating lexical $\mathrm{H}$ tones. Final Lowering does not apply to the object.
a. $\mathrm{CV} \mathrm{H}$
tò pén
'Buy a pen!'
b. $\mathrm{CVR}(\mathrm{V}) \mathrm{HL}$
nòm ìnsyù
'Drink water!'
c. $\mathrm{CVR}(\mathrm{V}) \mathrm{LH}$
dànè wò hó
'Turn yourself!'
d. CGV LH
bwà yàá
e. CVV LH
kàè kòfí
'Help Yaa!'
f. CVOV LH
bìsà àsćm
'Remember Kofi!'
'Ask something!' 


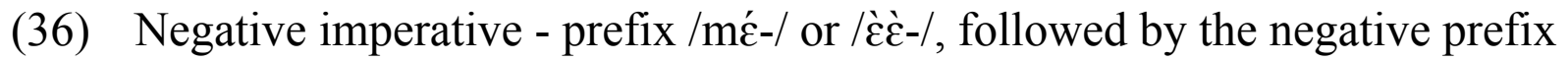
/̀̀-/
a. $\mathrm{CV} \mathrm{H}$
mé-ń-'tó pèn
$\sim$ غ̀े̀̀̀̀-tó pèn
'Don't buy a pen!'
b. CVR(V) HL
mé-ń-'nôm ìnsyù $\sim$ غ̇̀े-ǹ-nôm ìnsyù
'Don't drink water!'
c. $\mathrm{CVR}(\mathrm{V}) \mathrm{LH}$

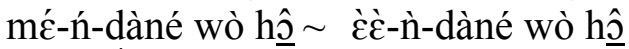
d. CGV LH mé-ḿ-'mwá yàà $\sim$ غ̇̀े-m̀-mwá yàà
'Don't turn yourself!'
e. CVV LH

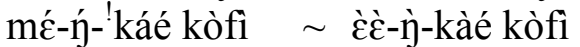
'Don't help Yaa!'
f. CVOV LH mé-ḿ-'mísá àsèm è̀-m̀-mìsá àsèm
'Don't remember Kofi!'
'Don't ask something!'

'Motional' ('come' and 'go') - L-toned prefixes /bغ̀-/ and /kò-/, respectively

a. $\mathrm{CV} \mathrm{H}$
ésí 'bé-tó-ò pèn
'Esi came and bought a pen.'
wó 'bé-tó-ò pèn
'You came and bought a pen.'
yàw bè-tó-ว̀ pèn
'Yaw came and bought a pen.'
mì bè-tó-ò pèn
'I came and bought a pen.'
ésí 'kó-tó-ò pèn
'Esi went and bought a pen.'
wó 'kó-tó-j̀ pèn
'You went and bought a pen.'
yàw kò-tó-ò pèn
ว̀ kò-tó-ò pèn
'Yaw went and bought a pen.'
'He went and bought a pen.'

b. CVR(V) HL
ésí 'bé-nôm-m̀ ìnsyù
'Esi came and drank water.'
wó 'bć-nôm-m̀ ìnsyù
'You came and drank water.'
yàw bè-nôm-m̀ ìnsyù
'Yaw came and drank water.'
mì bè-nôm-m̀̀ ìnsyù
'I came and drank water.'
ésí 'kó-nôm-m̀ ìnsyù
'Esi went and drank water.'
wó 'kó-nôm-m̀ ìnsyù
'You went and drank water.'
yàw kò-nôm-m̀̀ ìnsyù
j̀ kò-nôm-m̀ ìnsyù
'Yaw went and drank water.'
'He went and drank water.' 


\section{c. $\mathrm{CVR}(\mathrm{V}) \mathrm{LH}$}
ésí bè-dàné-è nè hô
'Esi came and turned herself.'

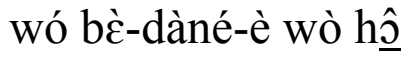
'You came and turned yourself.'
yàw bè-dàné-è nè hô
'Yaw came and turned himself.'
mì bè-dàné-è mì hô
'I came and turned myself.'
ésí kj̀-dàné-è nè hâ
'Esi went and turned herself.'
wó kò-dàné-è wò hô
'You went and turned yourself.'
yàw kò-dàné-è nè hô
'Yaw went and turned himself.'
mì kò-dàné-è mì hô
'I went and turned myself.'

\section{d. CGV LH (/CVV/)}
ésí bè-bwá-à yàà
'Esi came and helped Yaa.'
wó bè-bwá-à yàà
'You came and helped Yaa.'
yàw bè-bwá-à yàà
'Yaw came and helped Yaa.'
j̀ bè-bwá-à yàà
'He came and helped Yaa.'
ésí kj̀-bwá-à yàà
'Esi went and helped Yaa.'
wó kò-bwá-à yàà
'You went and helped Yaa.'
yàw kj̀-bwá-à yàà
'Yaw went and helped Yaa.'
mì kj̀-bwá-à yàà
'I went and helped Yaa.' 
e. CVV LH
ésí bè-kàé-è kòfî
'Esi came and remembered Kofi.'
wó bè-kàé-è kòfî
'You came and remembered Kofi.'
yàw bè-kàé-è kòfî
'Yaw came and remembered Kofi.'
yè bè-kàé-è kòfî
'We came and remembered Kofi.'
ésí kò-kàé-è kòfî
'Esi went and remembered Kofi.'
wó kò-kàé-è kòfî
'You went and remembered Kofi.'
yàw kò-kàé-è kòfî
'Yaw went and remembered Kofi.'
yè kò-kàé-è kòfî
'We went and remembered Kofi.'

\section{f. CVOV LH}

\begin{tabular}{|c|c|}
\hline ésí bè-bìsá-à àsèm & 'Esi came and asked something.' \\
\hline mó bè-bìsá-à àsèm & 'You pl. came and asked something.' \\
\hline yàw bè-bìsá-à àsc̀m & 'Yaw came and asked something.' \\
\hline ò bè-bìsá-à àsèm & 'He came and asked something.' \\
\hline ésí kò-bìsá-à àsèm & 'Esi went and asked something.' \\
\hline wó kò-bìsá-à àsèm & 'You went and asked something.' \\
\hline yàw kò-bìsá-à àsèm & 'Yaw went and asked something.' \\
\hline ò kò-bìsá-à àsèm & 'He went and asked something.' \\
\hline
\end{tabular}

\section{References}

Blevins, Juliette and Andrew Wedel. 2009. Inhibited sound change: An evolutionary approach to lexical competition. Diachronica 26.2: 143-183.

Boadi, L.A. 2008. Tense, Aspect and Mood in Akan. Pp. 9-68 in Felix K. Ameka and M.E. Kropp

Dakubu, eds. Aspect and Modality in Kwa Languages. Philadelphia: John Benjamins Publishing Company. 
Dolphyne, Florence Abena. 1965. The Phonetics and Phonology of the Verbal Piece in the Asante Dialect of Twi. PhD dissertation, University of London.

Dolphyne, Florence Abena. 1996. A Comprehensive Course in Twi (Asante) for the Non-Twi Learner. Accra: Ghana Universities Press.

Dolphyne, Florence Abena. 2006 (first printing 1988). The Akan (Twi-Fante) Language: Its Sound Systems and Tonal Structure. Accra: Ghana Universities Press.

Essilfie, Thomas. 1986. Some aspects of Aspect: The case of Akan. Ajia Afurika Gengo Bunka Kenkyû (Journal of Asian and African Studies [Tokyo]) 31: 6475 .

Gessner, Suzanne and Gunnar Ólafur Hansson. 2004. Anti-homophony effects in Dakelh (Carrier) valence morphology. Pp. 93-104 in Marc Ettlinger, Nicholas Fleischer, and Mischa Park-Doob, eds. Proceedings of the $30^{\text {th }}$ Annual Meeting of the Berkeley Linguistics Society. Berkeley, CA: Berkeley Linguistics Society.

Givón, Talmy. 1979. On Understanding Grammar. New York: Academic Press.

Heine, Bernd. 1993. Auxiliaries: Cognitive Forces and Grammaticalization. Oxford: Oxford University Press.

Lass, Roger. 1980. On Explaining Language Change. Cambridge: Cambridge University Press.

Lewis, M. Paul, ed. 2009. Ethnologue: Languages of the World, Sixteenth Edition. Dallas, Texas: SIL International.

Mondon, Jean-François. 2009. The Nature of Homophony and its Effects on Synchrony and Diachrony. $\mathrm{PhD}$ dissertation, University of Pennsylvania.

Noyer, Rolf 1994. Mobile affixes in Huave: Optimality and morphological wellformedness. Pp. 67-82 in Erin Duncan, Donka Farkas, and Philip Spaelti, eds. Proceedings of the Twelfth West Coast Conference on Formal Linguistics. Stanford: CSLI. 
Ofori, Seth. 2006a. Topics in Akan Grammar. PhD dissertation, Indiana University.

Ofori, Seth. 2006b. Recent-/remote-past marking in Akan: A multi-tiered account. Pp. 21-43 in Samuel Gyasi Obeng and Cecilia Sem Obeng, eds. From Linguistics to Cultural Anthropology: Aspects of Language, Culture and Family Issues in Ghana (West Africa).

Osam, Emmanuel Kweku Ahen. 1994. Aspects of Akan Grammar: A Functional Perspective. $\mathrm{PhD}$ dissertation, University of Oregon.

Paster, Mary. To appear. The role of homophony avoidance in morphology: A case study from Mixtec. In Proceedings of the $13^{\text {th }}$ Annual Workshop on American Indian Languages. UC Santa Barbara.

Saah, Kofi Korankye. 1994. Studies in Akan Syntax, Acquisition, and Sentence Processing. PhD thesis, University of Ottawa.

Schachter, Paul and Victoria Fromkin. 1968. A phonology of Akan: Akuapem, Asante, Fante. UCLA Working Papers in Phonetics 9.

Stump, Gregory. 2009. Cells and paradigms in inflectional semantics. Pp. 215233 in Erhard Hinrichs and John Nerbonne, eds. Theory and Evidence in Semantics. CSLI.

Mary Paster

Linguistics and Cognitive Science

Pomona College

Mary.Paster@,pomona.edu
Submitted: 16 July, 2010

Accepted: 28 November, 2010

Revisions: 12 December, 2010 
